\title{
CORRUPTION IN LAND ADMINISTRATION AND GOVERNANCE: A HURDLE TO TRANSITIONAL JUSTICE IN POST-APARTHEID SOUTH AFRICA?
}

\author{
Gaopalelwe Mathiba \\ LLB LLM (cum laude) \\ Lecturer, Faculty of Law, Rhodes University
}

\begin{abstract}
SUMMARY
The persistence of corruption in post-apartheid South Africa and the failure to control it adequately pose a significant threat to the country's transitional justice project and transformation imperatives. This article provides a detailed account of the depth and impact of corruption in land administration and governance in South Africa. It relies on the documented evidence of corruption scandals to establish the emerging trends, scope and impact of land-related corruption. The article is premised on the notion that corruption (which has become an intrinsic political norm in South Africa) not only impedes development and exacerbates rife inequalities in land ownership and access as a result of the apartheid regime, but also strangles the aims and objectives of transitional justice, which are to alleviate those inequalities. A further premise is that land-related corruption is a direct manifestation of untrammeled political power, patronage and impunity. The article problematises the latter premise and tackles the former by attempting to understand the complex interfaces between land, human rights, corruption and women in South Africa. Women are singled out from vulnerable groups because land ownership has traditionally been, and arguably still is, a male privilege. Of concern is the scale and pace of corruption, which boosts this anomaly, allowing it to thrive exponentially in post-apartheid South Africa. The article also presents a brief overview of operational and institutional challenges facing various initiatives aimed at combatting corruption generally. It concludes by proposing some realistic options to consider for the way forward.
\end{abstract}

\section{INTRODUCTION}

In South Africa, the land is without a doubt a vital resource, an important economic and cultural asset for both rural and urban communities. It is arguably also a key driver for economic growth and sustainable development. ${ }^{1}$ For this reason, therefore, how land is governed and

In many countries, the land is the fundamental factor shaping the country's wealth and development. Put differently, how land is used and administered determines the prospects of economic success in that particular country. This is so because it is at the point of land 
administered ought to feature significantly in both practice and policy reform debates. Over the past two decades, control over and access to land has been steered by various factors, including corruption, which has become a strategy and normalised way of living in post-apartheid South Africa. Certainly, the reform of land governance and administration in any country, especially developing ones, is a long-term prospect requiring decades of sustained commitment, a major investment of capital and transparent and accountable leadership in order to achieve development goals and sustainable outcomes. ${ }^{2}$

Therefore, the question this article seeks to address is whether land administration in post-apartheid South Africa is sufficiently resilient in the context of a high prevalence of corruption. The article argues that it is not satisfactorily resilient, at least to the extent envisioned by the Constitution of the Republic of South Africa, 1996 (the Constitution). ${ }^{3}$ A corollary of this observation is the argument that the key institutions and law enforcement agencies mandated to fight corruption have seemingly succumbed to political influences that divert their focus from the anti-corruption mandate. While this article maintains that the best and surest path to achieving equal access to land lies in the process of transitional justice, it is regrettable to note that corruption crushes these aspirations and reform potential.

The need for good governance in land administration is anything but new. A survey of recent literature affirms that land administration, if not properly managed through good governance practices, can be regressive and thus negatively affect the country's economic outlook and future prospects. ${ }^{4}$ What

that there is a convergence of all the key activities such as agricultural production (which is directly linked to food security), infrastructural development (which attracts foreign investments), forestry, industrialisation, urbanisation, biodiversity conservation, cultural and customary rights, and ecological and environmental protection.

2 Corruption may breed where government officials are afforded discretion without adequate accountability mechanisms, especially in government departments or agencies entrusted with the responsibility of distributing and providing services to the public, including land.

3 South Africa is counted among the countries with a strong and comprehensive anticorruption legal framework. While the Constitution makes no mention of "corruption", several constitutional provisions have a direct or indirect implication on the phenomenon. Furthermore, the Constitution not only establishes a number of institutions to enforce transparency and accountability of public officials, but also contains anti-corruption provisions that influence the entire public sector components such as administration, public service, security services, finances and others. Examples of these constitutional provisions include $s 32(1)(a)$ and $(b)$ (which provides for the right of access to information); s 33(1) and (2) (which provides for the right to administrative action that is lawful, reasonable and procedurally fair); s 182(1)(a) (which gives the Public Protector power to investigate any conduct in state affairs or in the public administration of any sphere of government that is alleged or suspected to be improper); s 188(1) (which requires the Auditor-General to audit and report on the accounts, financial statements and financial management of all state entities); s 188(2) (which authorises the Auditor-General to audit and report on the accounts, financial statements and financial management of any state-funded institution); s 195 (which outlines basic values and principles governing public administration) and s 215 (which requires national, provincial and municipal budgets and budgetary processes to promote transparency, accountability and the effective financial management).

4 Branson "Land, Law and Traditional Leadership in South Africa" Briefing note published by Africa Research Institute: Understanding Africa Today (2016) 1. See also Ocheje "In the Public Interest': Forced Evictions, Land Rights and Human Development in Africa" 2007 51(2) Journal of African Law 178 and Botha "Can Whistle-Blowing Be an Effective Good Governance Tool?” 2008 Journal of Contemporary Roman-Dutch Law 482-495. 
is particularly paralysing in South Africa is the lack of political will to confront corruption. Concerningly, the country is plagued with endemic fraud and corruption that permeates all sectors. Land governance is not immune from this problem. In fact, there is general consensus among experts that a lack of good governance in land administration processes is an Achilles heel of land reform in South Africa. ${ }^{5}$ This disconcerting trend has also recently been confirmed and noted with contempt by the Expert Advisory Panel on Land Reform and Agriculture in its famous report, namely Final Report of the Presidential Advisory Panel on Land Reform and Agriculture. ${ }^{6}$

To this end, all the narratives and discourses seem to point to a common conclusion that, in order to achieve an equitable distribution of land in line with the country's commitment to transitional justice and the objectives of the land reform project, improved land governance needs to be fostered and developed. ${ }^{7}$ Even so, there is still no clear direction and lead as to how exactly the government can walk this talk, and overcome the current corrupt land administration system to secure a more transparent and accountable one. At the receiving end of this problem are the poorest and marginalised class of society and vulnerable groups - that is, women, children and people with disabilities who are denied access to land. This has a negative bearing on human rights, ultimately defeating the country's commitment to transitional justice.

Against this background, this article explores the impact of land-related corruption on human rights generally and, in particular, on women in South Africa. The exploration is undertaken in the context of transitional justice. To be answered is the politico-legal question: can corrupt conduct in land governance be properly conceptualised, not only as a human rights violation but also as a threat to transitional justice imperative in South Africa? The answer is in the affirmative, i.e. indeed, endemic corruption in land governance in South Africa has long defeated the aspirations of transitional justice. The discussion unfolds as follows. The article begins with a clear explanation of the problem - that is, of corruption - and why it should be addressed systematically. It contends that the absence of clear policies, strong institutions, transparency, political goodwill and public participation, among other things, are the major causes of thriving corruption in land governance. It further outlines the anti-corruption legal framework, both in South Africa and at the international level. In doing so, it questions the lack of enforcement of these laws. Then, the article briefly discusses the impact of land-related corruption on human rights. Here it is argued that land-related corruption is a classical form of human rights violation and has not received adequate attention in transitional justice scholarship. Next, the article

5 See for e.g., Pienaar "Aspects of Land Administration in the Context of Good Governance" 2009 12(2) Potchefstroom Electronic Law Journal 15-16. See also USAID Land Tenure and Property Rights (2013) 16-17 https://www.land-links.org/wp-content/uploads/2016/09/ USAID_Land_Tenure_Framework.pdf (accessed 2020-06-26).

6 The Report (2019) is accessible online at https://www.gov.za/sites/default/files/gcis document/201907/panelreportlandreform_0.pdf (accessed 2019-08-23).

7 See generally Meer Women, Land and Authority: Perspectives from South Africa (1997); Walker "Women, Gender Policy and Land Reform in South Africa" 200532 Politikon 297-315; Walker "Elusive Equality: Women, Property Rights and Land Reform in South Africa” 200925 South African Journal on Human Rights 467-490. 
highlights a number of the impacts and ways in which land-related corruption affects women in South Africa. In conclusion, the article reflects on the implications of its analysis and demonstrates the regressive nature of landrelated corruption. The potential for corruption to defeat the aspirations of the country's transitional justice programme by stifling substantive gender equality for women with regard to land rights is also briefly outlined. In the last part, several suggestions are proffered for measures that could help to make the fight against corruption a reality and not just political rhetoric.

\section{METHODOLOGICAL APPROACH}

By its nature, corruption is a complex and multifaceted phenomenon with several causes and effects. It takes various forms and functions in a wide variety of contexts. For this reason, studies on corruption are often fraught with methodological complexities that require careful analysis. This is because of the contested nature of the evidence that is proffered to back up corruption claims in scholarly material. Given the serious legal implications attached to corruption claims, any evidence provided needs thorough verification and unsubstantiated claims have to be avoided at all costs.

As such, this article involves an in-depth analysis of the relevant readings. This kind of analysis entails an exploratory study based on desktop research that seeks to use already-existing information on alleged instances of corruption generally and in land administration in particular; the methodology is quantitative in approach. This approach provides the most effective way to a better understanding of the impact of land corruption on transitional justice in South Africa. To conceptualise this, the article places women's access to and ownership of land at issue.

In other words, the article does not feature field-based research. It relies significantly on already-documented evidence of corruption incidents in South Africa to establish the emerging trends, scope and impact of land corruption in particular. It is thus an analytic study of discourse that was purely desktop and library-based. The literature review includes both primary and secondary sources that are relevant to the subject matter of the article. The primary sources consulted comprise international and regional legal instruments on corruption, the Constitution, legislation, policy, case law and official documents of the South African government and other international and regional institutions. The secondary sources consulted include textbooks, journal articles, newspaper articles, conference papers and relevant verifiable Internet sources.

\section{STATEMENT OF THE PROBLEM}

Corruption, it is true, is a complex and multifaceted phenomenon. The specific focus on corruption in this article underscores the desperation and sense of urgency with which the author views its far-reaching impact on South Africa and its potential generally. By its very nature, corruption poses a significant threat to sustainable development, peace and stability in the country. It undermines all the efforts that have been made over the past two 
decades to reinforce and embrace the culture of good governance, democracy, transparency and regard for the rule of law. ${ }^{8}$

There exists a broad literature base on the concept of corruption and its construct from various perspectives. However, this does not necessarily cover the land governance aspect. Across the world, corruption is high on the human rights and sustainable development docket. South Africa is no exception. The country is plagued with corrupt activities that permeate all sectors, including land administration. This is evident from the report prepared by the Expert Advisory Panel on Land Reform and Agriculture, which confirms:

"There is growing evidence of corruption of various kinds in land reform ... some of this information is in the public realm. This pattern has been confirmed by Special Investigating Unit (SIU) investigations and proclamations." 9

This is fundamentally driven by an absence of clear policies, strong institutions, transparency and public participation, and perhaps inadequate resources as well. It goes without saying that improved land governance is key to ensuring the ultimate success of the land reform project. The former Secretary-General of the United Nations (UN), Kofi Annan posits:

"Corruption is an insidious plague that has a wide range of corrosive effects on societies. It undermines democracy and the rule of law, leads to violations of human rights, distorts markets, erodes the quality of life and allows organized crime, terrorism and other threats to human security to flourish. This evil phenomenon is found in all countries - big and small, rich and poor but it is in the developing world that its effects are most destructive." 10

International institutions are making calls to countries to stop corruption and take rigorous measures to rectify the damage it continues to cause. ${ }^{11}$ It is a most difficult exercise to find a common or universally accepted definition of corruption in literature. However, in the context of this article, it suffices to say that corruption is a phenomenon that generally arises where an individual or group of individuals exploit their positions of authority and trust by subverting rules to attract undeserved benefits. The understanding of corruption in various settings will always depend on the extent, degree and form of corruption committed.

8 See Fombad and Steytler Corruption and Constitutionalism in Africa (2020) general introduction.

9 See the Final Report of the Presidential Advisory Panel on Land Reform and Agriculture (2019) 12.

10 Annan "Foreword to the United Nations Convention Against Corruption" (2004) https://www.unodc.org/documents/brussels/UN_Convention_Against_Corruption.pdf (accessed 2020-05-09).

11 See, for instance, the UN General Assembly's Agenda 2030 for sustainable development of 2015, which calls out all states to be decisive on the anti-corruption project and appeals to all public officials to return stolen public resources by 2030 . 


\section{WHY CORRUPTION MATTERS IN LAND ADMINISTRATION?}

Corruption matters anywhere. Denying people equitable access to land as a result of corruption constitutes a human rights violation. This follows the sentiment held by an established academic discourse that conceptualises, in correct terms, access to land as a human right in its nature. It is thus almost impossible to talk about corruption in land governance without talking about the damage it causes - that is, as a human right (access to land) violation and the threat it poses to undermine the aspirations of the transitional justice project. The settled position is that corruption and human rights are intrinsically connected in the real-life experiences of people, especially the poor, in most parts of the world, including South Africa.

Broadly speaking, much as corruption matters in human rights work, it matters equally in land governance because it is a promising entry point to analyse and understand the acts and events that precede the violent act of human rights violations, particularly land dispossessions in South Africa, traceable from the apartheid regime. ${ }^{12}$ Alternatively put, corruption is a phenomenon not to be conceived of as an inconsequential anecdote in human rights discourse, analysis or activism. Furthermore, corruption and human rights violations, often termed as implied corporal violence, are the direct manifestations of the same root causes and are both the by-product and actual product of the same conditions. It is for this reason that the two should not be treated separately in policy or analysis in global and national efforts to improve the lives of the poor who suffer the most from systems engulfed by endemic corruption. This means that, for human rights research

12 In their article titled "The Natives Land Act of 1913 Engineered the Poverty of Black South Africans: A Historico-Ecclesiastical Perspective", Modise and Mtshiselwa provide a short and precise historical account of how black South Africans were dispossessed of their lands. They write: "Prior to the Natives Land Act of 1913 and the dispossession of land owned by black Africans was an era where very few natives experienced poverty. Thus, to strengthen the case that poverty was entrenched by such an Act and that the economic stability of the black South African was grounded in the use of land, we present a historical overview of land possession and usage. Maylam (1986:8) reports that in 1874 it was estimated that about five million acres of land owned by the colonists and companies were occupied by black South Africans. In this instance, they paid rent to the white landlords. It is difficult, though to be convinced that black South Africans generated wealth and/or economic welfare from renting land. Nonetheless, it seems evident that land was accessible to black South Africans, irrespective of land ownership. Furthermore, the mission stations were allocated areas of land, often amounting to between 6000 and 8000 acres for each station, for occupation by black South Africans (Maylam 1986:86). In this case, many black Africans did not own land. Instead, it is apparent that they partly benefited from the land allocation. Later in 1880, land purchased by black South Africans was more widely reported. To this end, land ownership and its productive use by black South Africans expanded. In addition, the acres of land owned by black South Africans expanded from 6000 to 8000 acres to 238473 acres of land in Natal by 1905 (Maylam 1989:86). Based on the evidence presented by Maylam, one can be certain that black South Africans owned and utilised land effectively for their welfare as well as for their economic stability prior to the Natives Land Act of 1913. If there had been no evidence of productive use of land by black South Africans as well as of their accumulation of productive land, the view that the Act under discussion engineered poverty would not stand. By productively using the land, the black Africans participated in the economic market of South Africa. Based on this, the discussion now turns to an inquiry into how the Nguni tribes and the Basotho people used their land in South Africa." 
and practice, it is pertinent to place corruption at centre stage and reflect on it beyond the orthodox.

It is important to acknowledge that a substantial amount has been written about the anti-corruption project in the context of the broader public sector in South Africa and globally. However, to date, an apparent vacuum is demonstrable from very limited academic work engaging at length with the existence and impact of corruption in land administration, particularly in South Africa, and how this mightily frustrates much-needed transformation through transitional justice. In many instances, this topic features only as an incidental issue, with minimal interest shown in exploring it in greater detail. The most cited piece in this regard, for South Africa, is Pienaar. ${ }^{13}$ Although Pienaar's work is a good point of reference in this topic and places good governance fittingly in the broader system of land governance, the author did not exhaust the topic. Commendably, the author appreciates this and states that this "is a topic that should be explored further, with a specific indication of what good governance principles should be applied to the different aspects of land administration in South Africa" and other related aspects.

The same can also be said of the work by Botha, ${ }^{14}$ who explores whistleblowing only as a potential mechanism to curb corruption in the public sector in general. The author does not link this to land administration necessarily and, as such, the piece might be of doubtful relevance to the direction taken by this article.

\section{TRANSITIONAL JUSTICE AND ITS ASPIRATIONS}

The previous sections have attempted to sketch out some of the issues that stand out most in contemporary South Africa concerning land policy and administration, and the socio-economic impact of policy decisions made by politicians in that regard. The next section entails the discussion of the South African anti-corruption legal framework, including the main institutions mandated to fight corruption in the public sector. It has been reported that contemporary land issues in South Africa have been occasioned by, among others: irregular land ownership patterns (race and gender disparities); inappropriate policies and priorities in resolving the concerns and issues relating to land access; and dishonest and unscrupulous administration characterised by fraud, corruption and the use of land as a political resource. ${ }^{15}$ The concerns, if not adequately addressed, can cause further serious human rights abuses with an immense negative and long-lasting impact on the country's development agenda. Thus, the transitional justice project is often undertaken in a context of severely compromised social institutions, the end result being gross human rights violations. ${ }^{16}$ In the particular context of this article, the violations upon which the transitional

Pienaar 2009 Potchefstroom Electronic Law Journal 15-55.

14 Botha 2008 Journal of Contemporary Roman-Dutch Law 482-495.

15 The Expert Advisory Panel on Land Reform and Agriculture Final Report of the Presidential Advisory Panel on Land Reform and Agriculture https://www.gov.za/sites/default/ files/gcis_document/201907/panelreportlandreform_0.pdf (accessed 2019-08-23).

16 See the UN "Guidance Note of the Secretary-General: United Nations Approach to Transitional Justice" file:///C:/Users/s2000156/Documents/TJ_Guidance_Note_March_ 2010FINAL.pdf (accessed 2021-01-27). 
justice imperative is brought to bear relate to equality rights of women in relation to land access and independent property (land) ownership as enumerated in the Constitution. ${ }^{17}$

Transitional justice is not "soft" justice. It constitutes, instead, an effort to provide the most meaningful justice possible in the political conditions at a particular time and space. The workable definition of "transitional justice", in the context of this article, is the one provided by the International Centre for Transitional Justice (ICTJ). According to the ICTJ, transitional justice refers to

"the ways countries emerging from periods of conflict and repression [such as Apartheid] address large-scale or systematic human rights violations so numerous and so serious that the normal justice system will not be able to provide an adequate response." 18

Furthermore, transitional justice is deeply grounded in accountability and redress for those who suffered from past atrocities and systematic repression. It is, by its nature, a corrective programme that recognises the dignity of victims and views them as worthy citizens and human beings deserving justice and protection of the law. The transitional justice programme is also rooted in the sentiment that "[i]gnoring massive abuses is an easy way out but it destroys the values on which any decent society can be built". ${ }^{19}$ These corrective mechanisms ask the most critical questions imaginable about the state of law and politics in a particular country. In so doing, they never forget to put victims and their dignity first, and point the way forward for a renewed commitment to ensure that ordinary citizens are safe in their own countries and protected against the unthinkable abuses of their authorities and others. ${ }^{20}$

In most countries where transitional justice is carried out, there is a bitter history of mass atrocities and systematic abuses that have left the societies devastated and hopeless. For instance, in South Africa, the apartheid regime left a legacy that makes the conditions of the country fragile, with political and legal institutions, the judiciary, state security and the prosecution authority being weak, unstable, politicised and under-resourced owing to corruption, patronage and elitism. The gross violations emanating from the bitter past have themselves substantially eroded the confidence that might have existed in the State to guarantee the rights and safety of citizens. Also, communities have often been ripped asunder in the process, with social and political organisations alike being severely weakened. Finding legitimate and reasonable responses to human rights violations under these real constraints of scale and societal fragility is the very essence of transitional justice and sets it apart from human rights promotion and advocacy mechanism in general.

$17 \mathrm{~S} 9$ of the Constitution provides that everyone is equal before the law and has the right to equal protection and benefit of the law, which includes the full and equal enjoyment of all rights and freedoms. S 25 goes further to guarantee that no one should be deprived of property arbitrarily.

18 See ICTJ "What is Transitional Justice" https://www.ictj.org/about/transitional-justice (accessed 2020-06-28).

19 lbid.

20 lbid. 
Insofar as the objective(s) of the transitional justice programme is concerned, it will always vary from one country to the other, depending on the context and reasons necessitating its invocation. For instance, in South Africa, the transitional justice programme is aimed at addressing the inequalities and systemic repressive legacies of the apartheid regime. Besides the objectives being largely dependent on the context, there are certain defining variables that are constant in most transitional justice programmes. These include, among others, the recognition of the dignity of individuals, the redress and acknowledgment of violations, restitution and compensation for any deprivation or dispossession and an undertaking to prevent them from recurring. Furthermore, it is often aimed at establishing strong and accountable state institutions and restoring confidence in them; ensuring respect for the rule of law; integrating women and marginalised groups in pursuit of a just society; devising strategies to address the underlying causes of ensuing conflicts and marginalisation and, most importantly, making access to justice a reality for the most vulnerable segments of the constituency. ${ }^{21}$

The ICTJ highlights that transitional justice may occur according to four traditional approaches. ${ }^{22}$ The first is by criminal prosecutions for at least those most responsible for the serious crimes of the past. Secondly, transitional justice may be pursued by "truth-seeking" or a fact-finding process into mass human rights violations by non-state bodies. The perfect example of this, in the context of South Africa, is the Truth and Reconciliation Commission (TRC), which invited witnesses identified as victims of gross human rights violations under the apartheid government to testify about their experiences. The third approach involves reparations, whereby those (individual, collective, material or symbolic) who are identified as victims of human rights violations are compensated for their suffering and harm. The last approach is the reform of laws and state institutions responsible for law enforcement, including the police, judiciary, military, and intelligence. This approach is the most prevalent in South Africa. This is evident from the fact that South Africa has a relatively strong anti-corruption legal framework (albeit ill-enforced), an aspect to which attention returns. However, it is contended that a lack of political goodwill poses the most challenging hurdle for South Africa to achieve reform through one of these four transitional justice approaches. This is well evidenced, for instance, by the apparent reluctance or lethargy of the political structures (in particular, Parliament) to finalise the Expropriation Bill, which would to a certain extent support the pursuit of justice for the dispossessed (blacks) and marginalised (women). 


\section{ANTI-CORRUPTION LEGISLATIVE FRAMEWORK IN SOUTH AFRICA: A GENERAL OVERVIEW}

\section{Constitutional framework}

The Constitution of the Republic of South Africa, 1996 serves as an important guidepost in all legal matters in the country. This includes corruption and the measures created to counter and deal with it. Although there is no express mention of the word "corruption" in the Constitution, several constitutional provisions have both direct and indirect bearing on corruption. This is seen from the fact that the Constitution establishes a number of institutions aimed at ensuring transparency and accountability for government officials. These include Chapter 9 independent institutions charged with a mandate of protecting constitutional democracy and advancing its enshrined values. The Constitution also contains several provisions on anti-corruption that span different government units, such as administration, social security, public service, security services and finance.

Constitutional provisions that are closely related to combatting corruption include section 32, which guarantees everyone the right of access to information; section 33, which provides for the right to administrative action that is lawful, reasonable and procedurally fair and the right to be given written reasons for a decision taken; and section 182(1)(a), which empowers the Public Protector to investigate any conduct in state affairs or in the public administration of any sphere of government that is alleged or suspected to be improper or that can potentially result in prejudice.

Furthermore, section 188 also mandates the Auditor-General to ensure accountability by conducting routine auditing and reporting on the status of accounts, financial statements and financial management of all state departments and administrations, municipalities and any other institutions or entities funded from the National Revenue Fund or a Provincial Revenue Fund. Also relevant is section 195, which outlines the fundamental values and principles guiding public administration. Lastly, section 215 requires national, provincial and municipal budgets and budgetary processes to abide by the transparency, accountability and effective financial management requirements imposed by the Constitution, and section 217 lays the constitutional basis for public sector procurement in the country.

\section{Legislative framework}

Corruption is dealt with, directly or indirectly, in several statutes in South Africa. The primary anti-corruption statute in South Africa is the Prevention and Combating of Corrupt Activities Act ${ }^{23}$ (PCCA). Commendably, the PCCA is a very comprehensive piece of legislation. In its preamble, it recognises that corrupt activities bear the potential to negatively affect constitutionally protected rights, sustainable development and the rule of law. It also recognises that corrupt activities have a notable negative bearing on democratic institutions, national economies and ethical values. The purpose

$23 \quad 12$ of 2004 . 
of the PCCA is to criminalise general corruption and various related activities. It places a positive duty on certain persons assuming positions of authority to investigate and report on any corrupt activities.

The PCCA also creates the general offence of corruption and related offences in respect of corrupt activities relating to public officers, members of the legislative authority, judicial officers and members of the prosecuting authority. ${ }^{24}$ Section 10 criminalises certain activities such as receiving or offering unauthorised gratification by or to a party to an employment relationship. Sections 11,12,13,14 and 15 provide a list of offences in respect of corrupt activities relating to witnesses and evidential material during certain proceedings, offences in respect of corrupt activities relating to the contract, procuring and withdrawal of tenders, auctions and offences in respect of corrupt activities relating sporting events.

The PCCA provides for the establishment and endorsement of a register to place certain restrictions on those persons and enterprises convicted of corrupt activities relating to tenders and contracts. In that regard, section $28(1)(a)$ and $(b)$ provides that where a person or enterprise has been found guilty and sentenced with regard to an offence of corrupt activities relating to contracts or tenders, that person or enterprise's name, conviction, sentence and the order made by the court will be endorsed in the register. Any other business or enterprise belonging to a person who has been convicted of corrupt activities, and that was involved in the commission of a crime, may also be entered into the register. Under section 32, this register becomes a public record. ${ }^{25}$

Another relevant anti-corruption statute in South Africa is the Prevention of Organised Crime Act. ${ }^{26}$ It provides for measures to combat organised crime, money laundering and criminal gang activities. Furthermore, the Act also prohibits certain activities that are linked to racketeering and provides for the prohibition of money laundering. An important aspect of the Act is that it creates an obligation to report certain information. In that regard, sections 2 to 6 provide for offences related to racketeering activities, money laundering, assisting a person to benefit from proceedings of unlawful activities and acquiring or using proceeds of unlawful activities.

Also relevant is the Protected Disclosures Act (PDA), ${ }^{27}$ which makes provision for the procedure in terms of which employees and workers, in the private and public sector may disclose information relating to unlawful or irregular conduct by their employers or employees. It also protects employees or workers who make such disclosure. The objects of the PDA, in terms of section 2, are to protect employees/workers from occupational detriment on account of making a protected disclosure, to provide remedies if the employee/worker has suffered an occupational detriment, and to provide procedures in terms of which the disclosure is made.

S 3-9 of PCCA

25 See further discussion on this in Mathiba "Corruption, Public Sector Procurement and COVID-19 in South Africa: Negotiating the New Normal" 2020 55(4) Journal of Public Administration 651-652.

26121 of 1998

2726 of 2000 . 
The Public Finance Management Act (PFMA) ${ }^{28}$ is another relevant statute. It was adopted to modernise financial management by ensuring transparency, accountability and the sound management of revenue, expenditure, assets and liabilities of provincial and national government. It sets out procedures for efficient and effective management of all revenue, expenditure, assets and liabilities. It also provides for certain responsibilities of persons entrusted with financial management in government. ${ }^{29}$

The Municipal Finance Management Act (MFMA) ${ }^{30}$ provides for the sustainable management of the financial affairs of municipalities and other institutions in the local sphere of government. The object of the Act is, inter alia, to ensure transparency, accountability, and appropriate responsibility in the financial affairs of municipalities and municipal entities. Accordingly, it provides the legal framework for the implementation of an integrated supply chain management process in local government.

Other relevant statutes include the Companies Act, ${ }^{31}$ the regulations of which create a duty to combat corruption, and which addresses certain issues relating to whistleblowers, and the Public Services Act, ${ }^{32}$ which provides for the organisation and administration of the public service. It also regulates conditions of employment and discipline within the public service. It should be noted that section 41(1)(b)(v) of the Act empowers the Minister to make regulations providing for a code of conduct in terms of which public servants must act in the best interests of the public, act honestly in dealing with public money and report fraud and corruption. The Code of Conduct for the Public Service prohibits employees from undertaking outside remunerative work without prior approval. ${ }^{33} \mathrm{~A}$ contravention of the Code amounts to misconduct. Another relevant statute is the Executive Members' Ethics Act (EMEA), ${ }^{34}$ which provides for the publishing of a code of ethics (after consultation with Parliament and by proclamation in the Government Gazette) governing the conduct of members of the Cabinet, Deputy Ministers and members of the provincial Executive Council.

In analysing South Africa's anti-corruption legislation, mention ought to be made of the Promotion of Access to Information Act (PAIA), ${ }^{35}$ which gives effect to the constitutional right of access to any information held by the State or by any other person. This Act is intended to foster a culture of transparency and accountability in public and private bodies. Similarly, the Promotion of Administrative Justice Act (PAJA) ${ }^{36}$ aims to give effect to the constitutional right to procedurally fair, lawful and reasonable administrative action.

Finally, mention also ought to be made of subsidiary legislation, such as the PFMA Regulations (which provide for a practical framework within which

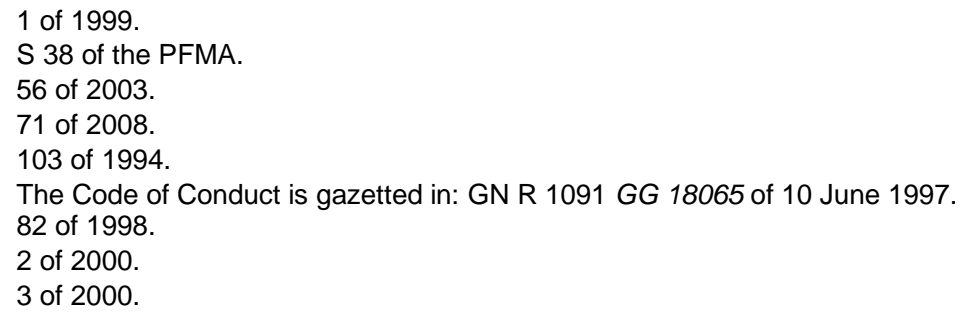


supply chain management practices are to take place), the MFMA: Municipal Supply Chain Management Regulations (which regulate the procedure for competitive bidding procurement) and the Preferential Procurement Policy Framework Act (PPPFA) Regulations (which provide for an operational framework for the preference point system envisaged in the PPPFA).

In sum, it is observable from the above discussion that the South African anti-corruption legal framework is a progressive one in many ways. However, despite having these progressive laws in place, corruption continues to thrive across the country. Little if any evidence exists to suggest that these anti-corruption measures are making headway in bringing corruption under control. Hence, the immediate question of practical relevance is why enforcement of these progressive laws fails? It is argued that this failure is attributable, in the main, to the endemic corruption that damages the institutional capacity and credibility of relevant state agencies adequately to dispense their mandate of ensuring compliance with these anti-corruption measures. It is for this reason, among others, that this article problematises land corruption as the most imminent threat to the transitional justice projects in South Africa.

\section{INTERNATIONAL INSTRUMENTS AGAINST CORRUPTION}

The primary international anti-corruption legal instrument is the United Nations Convention against Corruption (UNCAC). ${ }^{37}$ The focus of this instrument is on the prevention, criminalisation, international cooperation, asset recovery and implementation of anti-corruption mechanisms. South Africa is a signatory to this convention, having ratified it on 22 November 2004. The other important international legal instrument is the United Nations Convention Against Transnational Organised Crime (UNCTOC), ${ }^{38}$ which focuses mainly on the fight against organised crime, but includes several provisions relating to corruption. South Africa ratified the convention on 20 February 2004.

In the specific African context, the African Union Convention on Preventing and Combating Corruption (CPCC) ${ }^{39}$ is the continent's guidepost in the fight against corruption. Its main emphasis is on the need for member states to develop mechanisms for preventing, eradicating, and punishing acts of corruption. Although its content is comprehensive, the CPCC has over the years had a negligible impact on the laws and practice of its signatories. Article 7 of the Convention is dedicated to the fight against corruption and related offences in the public service and article 8(1) obliges state parties to create, within their domestic legal systems, an offence of illicit enrichment. South Africa ratified the CPCC on 11 November 2005.

Another international instrument that has a bearing on public corruption in Africa is the OECD Convention on Combating Bribery of Foreign Officials in

Adopted by the UN General Assembly on 31 October 2003, by Resolution 58/4.

Adopted by the UN General Assembly on 15 November 2000, by Resolution 55/25.

Adopted by the 2nd Ordinary Session of Assembly of the Union, Maputo on 11 July 2003. 
International Business Transactions. ${ }^{40}$ Its main purpose is to provide a framework for criminalising corruption in international business transactions. South Africa has long been a ratified party to this convention. There is also the 2011 UNCITRAL Model Law on Public Procurement, ${ }^{41}$ which contains international best practices on public procurement procedures and principles in a national setting. It also seeks to harmonise public procurement processes across nations. As far as South Africa is concerned, the Southern African Development Community Protocol against Corruption ${ }^{42}$ is also important.

\section{THE GENERAL IMPACT OF CORRUPTION ON HUMAN RIGHTS IN SOUTH AFRICA}

Wherever it occurs, corruption has the effect of channeling public funds and resources from their lawful and intended purposes into the pockets of unscrupulous public officials. As such, corruption has a devastating impact on the human rights of the majority of the population where, as in South Africa, that majority consists of poor people. The South African Constitution, particularly its Bill of Rights, is hailed as one of the most progressive in the world, mainly because it provides for all categories of human rights including socio-economic rights. By their nature, socio-economic rights have important social and economic dimensions, as they reflect specific areas of basic needs or delivery of particular goods and services. The delivery of such goods and services requires substantial budgets that are often allocated by the government. However, corruption has the effect of putting pressure on such budgets thereby undermining the quality of goods and services delivered and violating the socio-economic rights of the people. It is therefore submitted that the abuse of public funds meant for the provision of socio-economic goods constitutes a violation of socio-economic rights.

It is important to note that it is not only socio-economic rights that are negatively affected by corruption. Indeed, corruption affects all human rights, including civil and political rights. It is for this reason that the Constitutional Court held in South African Association of Personal Injury Lawyers v Health that

"corruption and maladministration are inconsistent with the rule of law and the fundamental values of our Constitution. They undermine the constitutional commitment to human dignity, the achievement of equality and the advancement of human rights and freedoms." 43

The Constitutional Court has since made several other pronouncements on the effect of corruption on human rights including in the case of Hugh Glenister v President of the Republic of South Africa, where it stated:

Adopted by the OECD Negotiating Conference on 21 November 1997.

Adopted by the UN General Assembly Resolution 66/95 of 9 December 2011.

Adopted by the Southern African Development Community (SADC) on 14 August 2001.

[2000] ZACC 22 par 4. 
"Endemic corruption threatens the injunction that government must be accountable, responsive and open .... It is incontestable that corruption undermines the rights in the Bill of Rights, and imperils democracy." 44

As already indicated above, South Africa is a democratic state. However, it must be pointed out that corruption has been identified as one of the greatest threats to this democracy. Reflecting on alliances that have emerged in post-apartheid South Africa, one commentator has warned against "corruptive collusions that ... run the risk of creating a parallel system of power that turns our democracy into an empty shell". ${ }^{45} \mathrm{~A}$ similar argument is made by Soma Pillay who contends that "corruption is likely to appear on every observer's list of factors that threaten to obstruct South Africa's path towards sustainable development". ${ }^{46}$ It may well be argued that by impacting democracy and sustainable development in South Africa, corruption also impacts human rights.

\section{LAND GOVERNANCE, LAND-RELATED CORRUPTION AND THE IMPACT ON WOMEN IN SOUTH AFRICA}

Generally, more men than women own land in South Africa. This gender gap in land beneficiation can be explained by many factors, and corruption is a key one. The gender disparity problem in relation to land ownership exists despite the Constitution's recognition of women as citizens who are equal to their male counterparts, ${ }^{47}$ and the fact that there are several pieces of legislation put in place to achieve equitable access to land through land reform projects and to eliminate the legal barriers towards the realisation of women's land rights. While South Africa's land reform project makes an explicit commitment to targeting women as beneficiaries, ${ }^{48}$ several analysts have argued that this objective has not been realised. ${ }^{49}$ The magnitude of the negative impact this bears on women cannot be quantified easily. In the absence of appropriate and gender-disaggregated data, the ability to assess the impact of land reform and related policies on women and gender inequalities is limited, as is the ability to design a more effective policy to

44 [2011] ZACC 6 par 176 and 177.

45 Bruce "Control, Discipline and Punish? Addressing Corruption in South Africa" 2014 SA Crime Quarterly 49-62 58.

46 Pillay "Corruption - The Challenge to Good Governance: A South African Perspective" 2004 17(7) The International Journal of Public Sector Management 586-605.

$47 \mathrm{~S} 9$ of the Constitution.

48 Walker 2005 Politikon 297-315.

49 See Chenwi and McLean 'A Woman's Home is Her Castle?' Poor Women and Housing Inadequacy in South Africa" 200925 South African Journal of Human Rights 517; Classens and Mnisi "Rural Women Redefining Land Rights in the Context of Living Customary Law" 200925 South African Journal of Human Rights 491; Walker 2005 Politikon 297; Hassim "Voices, Hierarchies and Spaces: Reconfiguring the Women's Movement in Democratic South Africa" 200532 Politikon 175; Claassens and Ngubane "Women, Land and Power: The Impact of the Communal Land Rights Act" in Claassens and Cousins (eds) Land Power and Custom; Controversies Generated by South Africa's Communal Land Rights Act (2008); Hargreaves and Meer "Out of the Margins and Into the Centre: Gender and Institutional Change" in Cousins (ed) At the Crossroads: Land and Agrarian Reform in South Africa Into the 21st Century (2000). 
address the problem. We turn to deal with the constitutional underpinnings that speak to the critical question of women and land.

\section{Women and land ownership: the constitutional context}

In post-apartheid South Africa, the constitutional foundations guiding the land reform programme are found in section 25 of the Constitution, often called the "property clause". 50 The property clause is a product of a highly fraught series of negotiations between the apartheid government and the African National Congress. ${ }^{51}$ Despite being fraught, these negotiations paved a way for the Interim Constitution of 1993, under which the first democratic elections of 1994 were held. Building upon the resolutions of the 1993 negotiations, the final Constitution of 1996 represents a substantial compromise and a balancing exercise between, on the one hand, respect for the established property rights of the white minority and, on the other, recognition of the restitutional and redistributive claims over land on the side of the black majority. Hence, alongside the entrenchment of the general right of people not to be deprived of property arbitrarily, but only "in terms of a law of general application", 52 section 25(4) of the Constitution goes on to affirm the public interest in a land reform programme as being designed specifically to bring about equitable access to all South Africa's natural resources.

In section 25(5), the State is required to take "reasonable ... measures, within its available resources, to foster conditions which enable citizens to gain access to land on an equitable basis". It is clear from the wording of section 25(5) that the State does not have a discretion on whether or not to embark on such a programme. This is seen from the use of the word "must", which implies a peremptory provision. However, in striving towards realising equitable distribution of land, the State is guided by two main considerations, namely reasonableness and availability of resources. In section 25(6), the State is once again required to pass sector-specific legislation to govern issues in relation to tenure (in)security spanning the past racially discriminatory laws and practices of the apartheid regime. In addition, there is section 25(7), wherein a provision is made for a land restitution programme aimed at addressing the land claims of those who suffered land dispossessions after 19 June 1913 as a result of past racially discriminatory laws and practices.

The most critical observation to make about section 25(5) is that it expressly acknowledges "equitable access" as a general principle applicable to the benefit of all citizens. This provision alone, therefore, confirms the unqualified right of all women not to be deprived of their rights in the land on account not only of their gender but, it is argued, on account of endemic land corruption as well. Thus, the State must act decisively to combat corruption that threatens women's right to land. It has a constitutionally imposed duty to

\footnotetext{
In particular, subsections 4-9.

See Walker 2009 South African Journal of Human Rights 481.

S 25(1) of the Constitution.
} 
respect, protect, promote and fulfil the rights contained in the Bill of Rights. In this regard, Walker argues that

\begin{abstract}
"the elimination of gender-based discrimination is not usually seen as the main concern of the property clause ... direct attention [is] specifically to remedying past racial discrimination, while the focus of the post-1994 land reform programme ... has certainly been on addressing the massively skewed land inequalities and injustices that are the result of South Africa's history of race-based oppression". 53
\end{abstract}

While this might be true - that land reform was "certainly" meant to address racial inequality - the author warns against a minimalistic approach towards gender aspects in the property clause. It is argued that gender-based discrimination is of equal concern and should not be seen as less deserving of being relevant to a land reform programme.

Alternatively put, the broader objective of land reform, it is argued, is not only to address racial inequality, but gender inequality as well. This means that any efforts intended to rectify the effects and patterns of the past racial discrimination in respect of black men, should apply equally to black women. The lack of focus on the issue of gender imbalance in land ownership is attributable, perhaps, to the specification and express mention of "race" by the Constitution, while it omits an express reference to "gender". This can also be explained by a deeply entrenched masculinity in the political norm in South Africa, which treats the subject of racial redress as being malecentered unless otherwise specified. Therefore, confronting gendered inequalities in land rights in South Africa means confronting first the construct and interpretation of the constitutional basis for land reform.

Also relevant is section 9 , which guarantees equality and, by my interpretation, recognises women as fully autonomous beings not to be discriminated against based on their gender. The section states that "[e]veryone is equal before the law and has the right to equal protection and benefit of the law" while subsection 9(3) rules out unfair discrimination on the grounds not only of "race" but also of "gender, sex, pregnancy, marital status, ethnic or social origin, colour, sexual orientation, age, disability, religion, conscience, belief, culture, language and birth". ${ }^{54}$ However, the right to equality, including for women, has always been countered with cultural rights in sections 30 and 31 of the Constitution respectively, some of which encompass patriarchal practices to the detriment of women. ${ }^{55}$

In balancing these seemingly conflicting rights through interpretation, the courts have to be cautious in ensuring that their interpretation points to these cultural rights not being exercised "in a manner inconsistent with any provision of the Bill of Rights". In other words, cultural rights, especially those entrenching patriarchal values, should not be exercised in a manner that infringe on the rights of everyone, including women, to equality. The Constitutional Court has rich jurisprudence on this aspect and has been very

53 See Walker 2009 South African Journal of Human Rights 482.

54 S 9(1) of the Constitution.

55 For example, in some communities, traditional leaders still prohibit women from having titles to land or assuming positions of leadership. See, for instance, the case of Shilubana $v$ Nwamitwa 2008 (9) BCLR 914 (CC). 
consistent, ${ }^{56}$ despite facing loud criticism from the traditionalists and proponents of patriarchy.

\section{The impact of land corruption on women in South Africa}

In South Africa, especially in the rural areas, the rights to have control over and use land are pertinent to the lives of rural women, whose lives and livelihoods are largely dependent on land and its natural resources. ${ }^{57}$ The marginalisation of women and girls in relation to land ownership, access and land rights not only undermines the transformative aspirations of the Constitution, but also threatens their living conditions, their economic empowerment and potential, their physical well-being and their struggle for equality within a deeply patriarchal society.

The other impact of land corruption on women is that it affects their economic potential negatively. The 2019 Report of the Presidential Advisory Panel on Land Reform highlights that "women in South Africa's rural societies are responsible for the majority of the agricultural food production and household labour". ${ }^{58}$ However, despite their significant contribution towards food production, women continue to suffer the scourge of gender discrimination. The patriarchal nature of South African society, especially in the rural areas, is such that women are unapologetically precluded from owning land and from putting it up as collateral to secure funding for expanding their farming operations or for debt management. The report of the panel observes that

"women are often overlooked [and undermined] when it comes to issues regarding land ownership although they are the ones that work it. Rules of access and inheritance in rural societies favour men over women and women with children over those without."59

This treatment (being considered useless or less important) also has negative emotional and psychological effects on women.

\section{CONCLUSION}

The current substantive realities around the land question and corruption in South Africa betray the underlying principles of justice and fairness, the guarantee of fundamental freedoms envisaged by the Constitution, and the enacted anti-corruption and land-related laws. Practically, decisive measures need to be taken to align these realities with the notions of justice. This article has attempted to contextualise this need in South Africa. The article has provided some insights into the emerging trends in land corruption. The

56 See, among others, Bhe $v$ Khayelitsha Magistrate 2005 (1) BCLR 1 (CC); Shilubana v Nwamitwa supra and Gumede (born Shange) $v$ President of the Republic of South Africa 2009 (3) BCLR 243 (CC).

57 See the Expert Advisory Panel on Land Reform and Agriculture Final Report of the Presidential Advisory Panel on Land Reform and Agriculture 36.

58 Ibid.

59 Ibid. 
article makes four key conclusions from the analysis of surveyed material. First, it is important to note that while land corruption is a relatively new phenomenon in South Africa's academic discourse, its gendered impact is immense and should never be underestimated. More policy strides are still needed to ensure gender equality in access to land. Secondly, it is observable from evidence in this article that political power is at the heart of any analysis of land-related corruption. In other words, corruption in South Africa is largely a function and abuse of political power as it occurs mainly in the public sector and through political offices. Thirdly, and related to this, is the apparent lack of political will to take a decisive stance against corruption by enforcing the comprehensive anti-corruption legal framework outlined above. The success and sustainability of good governance measures for land administration require the commitment of the government to act genuinely in bringing about tangible reforms rather than just having a "talk shop". One way of achieving good governance in land administration is to forge strong and credible state institutions to ensure the enforcement of and compliance with these measures but this has yet to be seen. Lastly, the article has briefly highlighted how land-related corruption erodes livelihoods and thus impacts negatively on marginalised groups - women in particular. While those in powerful positions accumulate wealth, it is the poor who suffer the brunt of corruption.

To this end, until all the necessary corrective measures are taken by the government to deal with corruption in the land sector, good governance in land administration will remain hypothetical. However, with a culture of good governance in land administration, more equitable access to land, the rule of law as well as the protection of citizens' rights (especially those of vulnerable social groups such as women and widows) can be realised, thus fulfilling the transitional justice aspiration. The corrective measures to achieve this include the creation and strengthening of mechanisms to monitor the implementation and effectiveness of anti-corruption and good governance measures in the land sector, and being prepared to take corrective steps where there are failures, or evidence of failures. As mentioned earlier, South Africa is renowned for its robust and comprehensive anti-corruption legal framework. However, this legal framework often fails owing to government actions of reluctance and lethargy towards its enforcement. Another factor accounting for this failure is the weak resilience of anti-corruption institutions and agencies, which are often alleged to succumb to political influences. 